\title{
Academics against Gender Studies
}

\section{Science populism as part of an authoritarian anti-feminist hegemony project}

\author{
By Marion Näser-Lather
}

\begin{abstract}
In Germany, knowledge production by gender researchers has been under attack not only from male rights activists, Christian fundamentalists and right-wing parties and movements, but also from scientists in various fields. Based on a discourse analysis of their publications (2009-2017) and a media reception analysis, this essay analyses arguments used by 'gender'-critical scientists and the socio-political backgrounds to where they position themselves. I show that their arguments do not belong to scientific discourse, but can be interpreted as a form of science populism which lends 'scientific' authority to the formation of authoritarian, anti-feminist discourses that aims to reify 'secure' knowledge about 'gender'. Accordingly, 'gender-critical' scientists are read mainly by non-scientific publics, including right-wing and Christian fundamentalist media and actors. As I will show, the phenomenon of scientists taking action against 'gender' can be situated in historical antifeminism, as well as contemporary discourses on the crisis-like character of the dynamics regarding gender knowledge and societal conditions.
\end{abstract}

KEYWORDS: anti-feminism, anti-genderism, science, populism, crisis, feminist knowledge production

MARION NÄSER-LATHER is a visiting researcher at the Helmut Schmidt University of Hamburg and lecturer at the University of Marburg, Germany. Among her research interests are antifeminism, protest movements, digitization and critical military studies. 


\section{Introduction}

In recent years, the hostility to Gender Studies has become increasingly intense. In Germany, gender scholars are being attacked by men's rights activists, conservative Christian movements like Demo für alle, and right-wing parties such as the Alternative für Deutschland (AfD). Within the scientific community, Gender Studies in Germany are supported by the German Ministry for Education and Research, as well as by scientific associations and university managements (e.g., see Berliner Rektorenkonferenz 2014, Deutsche Gesellschaft für Soziologie 2014), but even so the relevance of gender-related topics to research and teaching is increasingly being questioned in universities, with individual subjects resisting integrating gender perspectives into teaching and with equality measures being challenged (Marx/Kotlenga 2017, 13, 18). Moreover, scientists from different fields have positioned themselves against 'gender'.' Until now, attacks on Gender Studies by scientists have not been comprehensively investigated. Frey et al. classified researchers who oppose 'gender' as 'science guards', their term for a subgroup of anti-feminist actors (Frey et al. 2014a: 17f.). Manfred Köhnen (2014) exposed arguments of the blog "Science Files" as unscientific. By investigating scientists arguing against 'gender', the potency and popularity of contemporary antifeminist discourses can be demonstrated. ${ }^{2}$ In this article I will show how 'gender-critical' scientists are invoking unscientific arguments lacking in validity that are nonetheless being received by certain (sub)public spheres for which they have enhanced interpretative power. This is because the scientific level of discourse still functions as the final authority in everyday discourses.

In the following, I briefly outline gender-critical arguments based on my previous discourse analysis (Jäger 2009) of their publications (20092017) before illuminating their arenas of discourse. Finally, I offer a tentative contextualization of their arguments by classifying them and their reception as an effect of current anti-diversity tendencies that are impacting on gender, following Ilse Lenz (2013).
Of the ten scientists selected for this analysis, one third come from the natural sciences, the remainder from the humanities and social sciences. Most of them have high potential interpretative power in different publics. Some are renowned in their fields, such as the sociologist Gerhard Amendt and the biologists Ulrich Kutschera and Axel Meyer, while others hold professorships or are emeriti, like the economist Günter Buchholz, the Christian social scientist Harald Seubert and the neuroscientist Manfred Spreng. Some are influential in professional societies and associations, like the Christian social scientist Manfred Spieker, consultant to the Pontifical Council for Justice and Peace, and the Christian philosopher Hanna Barbara Gerl-Falkovitz, Vice President of the Edith Stein Society Germany. Others run influential right-wing blogs, like the sociologist Heike Diefenbach, or are prominent authors of rightwing online-journals, such as the philosopher Alexander Ulfig (see Näser-Lather 2019: 117). Although some of these figures have published on topics that fall within the scope of gender research, such as Amendt (2006), Diefenbach (e.g. 2010) and Gerl-Falkovitz (1988), the others do not have any expertise in this topic.

\section{Discourses of Devaluation and Demonization}

The arguments of these scientists resemble those of anti-feminist actors, there being two main strands of discourse: (a) devaluing Gender Studies as unscientific; and (b) demonizing Gender Studies as a danger to society.

The discursive strand of unscientific work includes the 'gender' critical scientists accusations that gender researchers are ideologists (e.g. $\mathrm{T}^{3}$, $\mathrm{T} 2 ; \mathrm{T} 7,5 ; \mathrm{T} 4 ; \mathrm{T} 8$, pos. $5355 ; \mathrm{T} 9,263, \mathrm{~T} 10,56)$ : from the notion of the situatedness and context-dependence of knowledge, this approach charges that Gender Studies' search for knowledge is influenced by financial and political ends, such as lobbying for women's interests and university positions and indoctrinating students: 'Partisanship becomes an important principle of scientific work. 
This paves the way for the extensive instrumentalization of science for political purposes' (T13, 14). ${ }^{4}$

Gender Studies are also accused of claiming that cultural influences are the only relevant factors in gender and gender relations and of ignoring the significance of the body accordingly. In this view, Gender Studies are concerned to 'deny the often considerable influence of our biological heritage on many aspects of human life' (T8, pos. 135; also see T1; T3; T6, pos. 2022; T7, 200). Furthermore, 'gender-critical' scientists argue that the 'radical' constructivism they ascribe to Gender Studies makes knowledge impossible because, if everything is assumed to be constructed, the truth of statements cannot be verified $(T 9,258 ; T 13$, 14f.).

Moreover, 'gender' is presented as dangerous to men, women and families: 'the attempt to prevent identity formation in favour of an individualistic society without "real fathers and mothers" is therefore a danger to the individual organism and above all to the family' (T11, 70; also see T10; T3). In addition, Gender Studies endanger children by promoting 'early sexualisation' and paedophilia $(T 7,388 ; T 10 ; T 11,72)$ and destroy society because they lead to a loss of values and norms ( $T 6$, pos. $2141 ; T 7,327 ; T 9,258 ; T 10,64)$, for example, because homosexuality and heterosexuality are regarded as ethically equal ( $T 6$, pos. $2141 ; T 10$, 40).

In addition, it is claimed that science is being endangered by Gender Studies because of the appointment of gender professorships and the growing influence of gender theories. Gender Studies threaten freedom of research and teaching, ideologize subjects ( $T 4 ; T 5,92 ; T 7,96,121 ; T 8$, pos. 5355-5361; T9, 268; T13, 130-132) and deprive other subjects of resources. Moreover, science generally is suffering a loss of reputation as a result of gender research (T7, 399): 'Gender Studies harm science, especially the social sciences' (T5, 85).

Yet, the question remains whether or not these accusations are actually more applicable to the publications of gender-critical scientists themselves.

\section{Unscientific 'Guardians of Science'}

It can indeed be argued that the texts of 'gender-critical' scientists, albeit to varying degrees, do not meet scientific standards themselves. Some of them combine criticism in the sense of content-related arguments with defamation, rhetorical tricks and ideological messages.

Misleading or even false representations are used in order to impugn Gender Studies. Strawman arguments are used about Gender Studies by attributing claims to them which scholars in the discipline would not support: 'Everything is "socially constructed", even the anatomy of the sexual organs, is the [...] credo of the gender believers' (T7, 200).

'Gender-critical' scientists also employ inappropriate analogies and false correlations $(\mathrm{T} 1, \mathrm{~T} 2$, T10, T13), such as associating Gender Studies with creationism $(T 7,7)$ or communism $(T 7,44)$. Conspiracy narratives are used to fuel fears of 'gender ideology' (e.g. in T4; T7, 5, 27, 44-47, 399; T8, pos. 5484; T3; T10; T6, pos. 2141): for instance, the discipline was accused of planning to promote homosexuality, attack Christian values and abolish gender at the 1995 World Conference on Women in Beijing (T7, 44-47; T10, 11, 37), and T2 even goes so far as to suspect a 'state-feminist complex'.

Some texts use derogatory terms and defame 'gender' with negative associations, insults and pathologies (T3, T5, T6, T8, T10), for example, when insinuating that gender researchers suffer from 'penis envy' (T1) or referring to them as 'childless and lesbian [...] butch women' $(T 7,398)$. By making this connection with devalued subject positions, the knowledge of gender researchers is condemned as invalid.

Another rhetorical trick is to scandalize the normal: Gender Studies are accused of unjustifiably situating the category of gender at the centre in order to satisfy certain interests: 'If, on the other hand, women's and gender studies are seen as a special science policy context and exist as such, then this only makes sense with regard to an unspoken preconception, to a guiding ideology, which from the scientific point of view, however, 
should not play a role' (T3; also see T5; T12). The fact that different research perspectives illuminate their subjects by adopting a specific focus is scandalized and interpreted as an epistemological fault.

Some authors draw false conclusions from which they derive impermissible generalisations, for instance, deducing the extent of female violence from 'the countless anecdotes about wives with the frying pan behind the door' (T1). Others commit naturalistic fallacies, inferring from a momentary state of things to a moral imperative by demanding that we make socio-political decisions on the basis of biological 'facts' or 'facts' given by the order of creation ( $T 7,93$; $T 8$, pos. 128 ; T10, 61).

Some texts contain hardly any scholarly references (e.g. in T8) resorting instead to inaccurate quotations and dubious sources: in discussing the decisions of the World Women's Conference in Beijing, for example, the official UN documents are not cited, but rather the notes of the fundamentalist Catholic thinker Dale O'Leary (T7, 44-47; T10, 37).

In view of these shortcomings, it can be argued that some of the scientists who criticize 'gender' and Gender Studies do not fulfil the scientific criteria they themselves claim to observe. Their texts are thus situated at the intersection of non-scientific inter-discourse and special scientific discourse. They also use their professional status to express their views on social policy. This is problematic because they position themselves as representatives of the scientific community by calling their publications 'reference books' or 'science blogs' and by referring to their academic titles and publications while at the same time lacking scientific rigour.

As Bourdieu $(1991,7)$ notes, in the academic field social authority is legitimised by presenting itself as strictly professional, while status authority modifies social perceptions of professional ability. This also seems to apply here: because of their symbolic capital as representatives of their respective disciplines, 'gender-critical' scientists are accorded authority in the sense of secular scientific capital in areas they do not in fact represent.

\section{Influence in (Sub-)Publics}

The arguments of these scientists are used in public discourses as a means of interpretation. As supposed experts on gender issues, they have an impact especially on conservative, right-wing and Christian fundamentalist publics.

These scientists are all cited as experts on 'gender' in media and online platforms, such as right-wing media like Sezession, Freie Welt or Compact magazine, and on Christian platforms like kath.net (see Näser-Lather 2019, 117). 'Gender-critical' scientists are also invited to be interviewed by actors on the conservative, right-wing, Christian fundamental spectrum, such as the Congress of Christian Leaders and the Christian-right conservative movement Demo für Alle. For example, Gerl-Falkovitz was commissioned by the German Bishops' Conference to assess gender theories, and she was invited by the renowned Konrad Adenauer Foundation, which is close to the Christian Democratic Party CDU, to give a lecture at a conference they organized. The programme flyer stated that Prof. Dr. Ulrich Kutschera had proved that Gender Studies were unscientific (see ibid.). The arguments of 'gender-critical' scientists have also been adopted by the right-wing AfD party in minor inquiries in state parliaments and the German federal parliament (kleineanfragen.de 2019). On online platforms and right-wing blogs in particular, these critics' arguments are used to lend anti-feminist and anti-Gender Studies arguments the appearance of scientific authority as a way of legitimizing them.

\section{Localization and Discursive Background}

This use of academic knowledge in anti-feminist arguments has historical parallels in the beginning of the twentieth century, when the emancipation efforts of the women's movement were countered by naturalizing gender characteristics in a way that was justified both scientifically and religiously (Planert 1998, 14-20). Then as now the scientific level of discourse functions as an 
instance of final justification, of establishing a discourse position that carries authority, in what is an ideological counter-movement against the liberalisation of gender orders.

Following Ilse Lenz (2013), it can be argued that the gender order is on a path towards flexibilization, which implies a transformation of gender roles and the increased presence of non-normative ways of life. Paula Irene Villa $(2017,100)$ draws attention to a loss of normality, of naturalized stabilizations and 'natural' subjects and identities. This loss of certainties can result in fear and disorientation and can cause a rejection of this transformation (Chmilewski/Hajek 2017), as well as a need for reliable gender knowledge. The positive reception given to 'gender-critical' scientists can be explained by the fact that they meet this need. Their arguments are especially well aligned with the world views of right-wing conservative and fundamentalist religious actors, who, as Birgit Sauer (2018) has pointed out, fight against the threat and uncertainty of gender identities and reject the notion of the pluralization of life forms. Thus, anti-feminist arguments function as a symbolic toolkit that unites right-wing, conservative, ultra-religious movements and groups (Kováts/Põim 2015, Kemper 2014), being part of a socio-political authoritarian-regressive project that is fighting for hegemony and rejecting any questioning of the alleged binary gender order (see Fritzsche/Lang 2019).

\section{Conclusion}

The analysis shows that the texts written by 'gender-critical' scientists defame Gender Studies by denouncing them as unscientific and as a danger to society, while they themselves employ unscientific techniques such as false or distorted representations, defamations, false conclusions, impermissible generalisations and conspiracy narratives. Nonetheless, these texts are positively received, especially by fundamentalist Christian and conservative/right-wing publics, because their arguments are well aligned with their struggle against a more diverse gender order. Thus, 'scientifically' legitimized and ennobled positions are still attributed some interpretive power in these publics. Unfortunately, however, only 'scientific results' that confirm a certain type of closed world view seem to be accepted. This problem is further exacerbated because of the general tendency towards the socio-intellectual segregation of 'mainstream' publics, media and science, whereby populist/right-wing publics consider science to be 'leftist' and untrustworthy. The only chance for Gender Studies to counter these 'gender-critical' discourses is to try to communicate science accurately and adequately. There is still a 'silent majority' of society that has not yet disappeared into an ideological filter bubble. In striving to reach this 'silent majority,' it is important that we insist upon maintaining high scientific standards in our scientific communications. We must also insist that both Gender Studies itself, like other scientific disciplines, are held to such standards in order to reinforce confidence in science communication and discourse. 


\section{Notes}

1 In the texts of these authors, the word 'gender' is used as an empty signifier under which different phenomena, such as equality feminism, difference- and queer feminism, gender mainstreaming, gender studies and the liberalisation of gender relations, are subsumed (see Näser-Lather 2019, 107).

2 In this context I define anti-feminist discourses, following Lang and Fritzsche $(2018,340)$, as those which oppose the liberalization and denormalization of gender relations, deny feminist critiques any justification and are partly misogynous and homo- or transphobic - positions which also appear in most of the texts I have analysed (e.g.T1; T9, 116, 337; T11, 131; T13, 40), while others only express gender-conservative views (e.g. T8).

3 As the focus of my analysis is on patterns of argumentation, I do not refer to authors, but to texts (T1... $\mathrm{Tn}$; see list of sources).

4 All direct quotes have been translated by myself.

\section{Sources}

Gerl-Falkovitz, H. B. 1988. Die bekannte Unbekannte. Frauen-Bilder aus der Kultur- und Geistesgeschichte. Mainz: Grünewald Verlag.

kleineanfragen.de. 2019. Anfrage der AfD im Bundestag ,Genderkritik und die Gefahr der Spaltung der Gesellschaft durch Misandrie'. [Online]. [Accessed 29 November 2019]. Available from: https://kleineanfragen.de/bundestag/19/8788-genderkritik-und-die-gefahr-der-spaltung-der-gesellschaft-durch-misandrie

T1 = Amendt, G. 2016. Neid und Missgunst - der schwankende Unterbau der Gender Studies. [Online]. [Accessed 28 April 2018]. Available from: https://www.cuncti.net/geschlechterdebatte/936-neid-und-missgunst-der-schwankende-unterbau-der-gender-studies

T2 = Buchholz, G. 2014. Gender Studies - Die Niedersächsische Forschungsevaluation und ihre offenen Fragen. [Online]. [Accessed 28 august 2019]. Available from: https://serwiss.bib.hs-hannover.de/ files/405/Gender_Studies_-_Die_Nieders\%C3\%A4chsische_Forschungsevaluation_und_ihre_offenen_ Fragen.pdf

T3 = Buchholz, G. 2016. Sind ,Gender Studies' Wissenschaft? [Online]. [Accessed 30 April 2018]. Available from: [https://www.cuncti.net/geschlechterdebatte/947-sind-gender-studies-wissenschaft

T4 = Diefenbach, H. 2013. Brauchen wir Professuren für Genderforschung an Universitäten und Hochschulen? [Online]. [Accessed 21 January 2018]. Available from: https://sciencefiles. org/2013/08/09/brauchen-wir-professuren-fur-genderforschung-an-universitaten-und-hochschulen/

T5 = Diefenbach, H. 2019. ,Gender Studies'. Politische Ideologie statt Sozialwissenschaft. In: Schulze-Eisentraut, H., and Ulfig, A. eds. Gender Studies. Wissenschaft oder Ideologie? Baden-Baden: Deutscher Wissenschafts-Verlag, 84-124.

T6 = Gerl-Falkovitz, H. B. 2009. Frau - Männin - Menschin. Zwischen Feminismus und Gender. Kevelaer: Topos.

T7 = Kutschera, U. 2016. Das Gender-Paradoxon. Mann und Frau als evolvierte Menschentypen. Berlin: LIT.

T8 $=$ Meyer, A. 2015. Adams Apfel und Evas Erbe: Wie die Gene unser Leben bestimmen und warum Frauen anders sind als Männer. München: Bertelsmann.

T9 = Seubert, H. 2014. Zuhause sein im Leib? Überlegungen zu Gender und Sexualität. In: Klose, J. ed. Heimatschichten. Wiesbaden: Springer VS, 257-289.

T10 = Spieker, M. 2015. Gender-Mainstreaming in Deutschland. Konsequenzen für Staat, Gesellschaft und Kirchen. Paderborn: Schöningh. 
T11 = Spreng, M. 2015. Adam und Eva - Die unüberbrückbaren neuro-physiologischen Unterschiede. In: Späth, A., and Spreng, M. eds. Vergewaltigung der menschlichen Identität: Über die Irrtümer der Gender-Ideologie. Ansbach: Logos Editions, 35-74.

T12 = Ulfig, A. 2014. Der Mythos von der ,sozialen Konstruktion'. [Online]. [Accessed 24 September 2018]. Available from: https://www.cuncti.net/wissenschaft/525-der-mythos-von-der-sozialen-konstruktion. $\mathrm{T} 13$ = Ulfig, A. 2016. Wege aus der Beliebigkeit: Alternativen zu Nihilismus, Postmodere und Gender-Mainstreaming. Baden-Baden: Deutscher Wissenschafts-Verlag.

\section{References}

Berliner Rektorenkonferenz. 2014. Diffamierungen und Gewaltandrohungen gegenüber Wissenschaftlern sind inakzepabel. [Online]. [Accessed 2 September 2019]. Available from: https://www.hu-berlin.de/de/ $\mathrm{pr} /$ nachrichten/archiv/nr1412/nr_141215_00.

Chmilewski, K., and Hajek, K. 2017. Mit Gefühl von Rechts zur Verteidigung der ,Lufthoheit über Kinderbetten'. In: Bargetz, B., Kreisky, E., and Ludwig, G. eds. Dauerkämpfe. Feministische Zeitdiagnosen und Strategien. Frankfurt am Main/New York: Campus Verlag, 175-184.

Deutsche Gesellschaft für Soziologie (2014): Erklärung der Deutschen Gesellschaft für Soziologie (DGS) zu aktuellen Kampagnen der Diskreditierung und Diffamierung von Wissenschaftlerinnen und Wissenschaftlern. [Online]. [Accessed 1 November 2017]. Available from: https://www.soziologie.de/de/ nc/aktuell/stellungnahmen/single-view/archive/2014/07/23/article/erklaerung-der-deutschen-gesellschaft-fuer-soziologie-dgs-zu-aktuellen-kampagnen-der-diskreditierung.html.

Frey, Regina/Gärtner, Marc/Köhnen, Manfred/ Scheele, Sebastian. 2014a. Einleitung zur zweiten Auflage. In: Dies., Gender, Wissenschaftlichkeit und Ideologie. Argumente im Streit um Geschlechterverhältnisse, Berlin: Heinrich-Böll-Stiftung. 9-27. [Online]. [Accessed 23 August 2019]. Available from: https:// www.boell.de/sites/default/files/gender_wissenschaftlichkeit_ideologie_2.auflage.pdf.

Frey, Regina/Gärtner, Marc/Köhnen, Manfred/ Scheele, Sebastian. 2014b. Gender, Wissenschaftlichkeit und Ideologie. Argumente im Streit um Geschlechterverhältnisse. Berlin: Heinrich-Böll-Stiftung. [Online]. [Accessed 23 August 2019]. Available from: https://www.boell.de/sites/default/files/gender_wissenschaftlichkeit_ideologie_2.auflage.pdf.

Fritzsche, C., and Lang, J. 2019. „Ein Papa, eine Mama, ganz einfach!': Eine hegemonietheoretische Analyse der Gegnerschaft zur „Ehe für alle'. PROKLA. Zeitschrift für Kritische Sozialwissenschaft, 49(197), 515-531. [Online]. [Accessed 12 March 2018]. Available from: https://www.prokla.de/index.php/PRO$\mathrm{KLA} /$ article/view/1843

Jäger, S. 2009. Kritische Diskursanalyse. Eine Einführung. 5. Auflage. Münster: Unrast-Verlag.

Kemper, A. 2014. Keimzelle der Nation. Familien- und geschlechterpolitische Positionen der AfD. Berlin: Heinrich Böll Stiftung. [Online]. [Accessed 05. February 2019]. Available from: http://www.gwi-boell.de/ sites/default/files/uploads/2016/08/input_keimzelle_der_nation_afd_andreas_kemper_endf_0.pdf

Kováts, E., and Põim, M. eds. 2015. Gender as symbolic glue. The position and role of conservative and far right parties in the anti-gender mobilizations in Europe. Budapest. [Online]. [Accessed 05 February 2019]. Available from: http://library.fes.de/pdf-files/bueros/budapest/11382.pdf

Kurz-Scherf, I. 2018. Was ist falsch am Kapitalismus und seiner Kritik? Oder hatte Karl Marx vielleicht doch (nicht) recht? In: Scheele, A., and Wöhl, S. eds. Feminismus und Marxismus. Weinheim: Beltz-Juventa, 59-83.

Lang, J., and Fritzsche, C. 2018. Backlash, neoreaktionäre Politiken oder Antifeminismus? Forschende Perspektiven auf aktuelle Debatten um Geschlecht. Feministische Studien 2, 335-346.

Lang, J., and Peters, U. 2018. Antifeminismus in Deutschland. Einführung und Einordnung des Phäno- 
mens. In: Lang, J., Peters, U. eds. Antifeminismus in Bewegung. Aktuelle Debatten um Geschlecht und sexuelle Vielfalt. Hamburg: Marta Press, 13-36.

Lenz, I. 2013. Geschlechterkonflikte um die Geschlechterordnung im Übergang. Zum neuen Antifeminismus. In: Appelt, E., Aulenbacher, B., and Wetterer, A. eds. Gesellschaft. Feministische Krisendiagnosen. Münster: Westfälisches Dampfboot, 204-226.

Köhnen, M. 2014. Der Unwissenschaftlichkeitsvorwurf - Zum Alleinvertretungsanspruch eines speziellen Wissenschaftsverständnisses. In: Frey/Gärtner/Köhnen/Scheele: Gender, Wissenschaftlichkeit, Ideologie, 51-64.

Marx, D., and Kotlenga, S. 2017. Übliche Widerstände oder neue Infragestellungen? Gleichstellungsfeindlichkeit und Angriffe auf Gleichstellungsarbeit an Hochschulen in Niedersachsen. [online]. [Accessed 05 June 2019]. Availlable from: https://www.nds-lagen.de/download/Berichte/Abschlussbericht_LNHF-Projekt_Antifem_final_Sept_2018.pdf.

Näser-Lather, M. 2019. „Wider den Genderismus!' Kritik und Polemiken gegen die Gender Studies in akademischen Kontexten. In Näser-Lather, M., Oldemeier, A. L., and Beck, D. eds. Backlash?! Antifeminismus in Wissenschaft, Politik und Gesellschaft. Sulzbach/Taunus: Helmer Verlag, 105-127.

Planert, U. 1998. Antifeminismus im Kaiserreich: Diskurs, soziale Formation und politische Mentalität. Göttingen: Vandenhoeck \& Ruprecht.

Sauer, B. 2018. Why 'Gender' is Crucial for the Analysis of Authoritarian Right-wing Populism. Keynote held at the workshop 'right-wing populism and gender', Bielefeld 23.11.2018 (unpublished).

Schmincke, I. 2018. Frauenfeindlich, sexistisch, antifeministisch? Begriffe und Phänomene bis zum aktuellen Antigenderismus. Aus Politik und Zeitgeschichte 17, 28-33.

Villa, P.-I. 2017. „Anti-Genderismus': German Angst? In: Kuhar, R., and Paternotte, D. eds. Anti-Gender Campaigns in Europe. Mobilizing against Equality. London/New York: Rowman \& Littlefield International, 99116. 